FOLIA SCANDINAVICA VOL. 19 POZNAŃ 2016 DOI: $10.1515 / \mathrm{fsp}-2016-0019$

DE DE GRUYTER OPEN

\section{PRESSto.}

\title{
PÅ SPANING EFTER EN HALVGLÖMD GENRE:
}

\author{
LITANIAMINNEN I "BÖN TILL SOLEN" \\ AV KARIN BOYE
}

\author{
MAGDALENA ŻMUDA-TRZEBIATOWSKA \\ Adam Mickiewicz University in Poznań
}

ABSTRACT. The article is a presentation of partial research on litanic verse in Swedish literature carried out within the project "Litanic Verse in the Culture of European Regions". Starting from the origins of the litanic genre, described by Witold Sadowski, the author analyses Karin Boye's poem "Bön till solen” (,Prayer to the Sun"), paying special attention to the presence of the three litanic genes: the ektenial, the polyonymic and the chairetismic. As the typical stylistic figures and structural solutions occur in the poem, a conclusion can be drawn that "Bön till solen" is an example of preservation of litanic patterns in the Swedish literary tradition.

Enligt en enkel ordboksdefinition är litania "en längre kyrkobön som framförs genom växelsång mellan prästen och församlingen" (Svensk ordbok, 1990). I uppslagsboken karakteriseras litania som "en förbönstyp, där de oftast $\mathrm{i}$ stenstil angivna böneämnena ständigt åtföljs av menighetens bönerop" (Bra Böckers Lexikon, 1977). De kortfattade definitionerna tycks vara förankrade i den protestantiska kyrkotraditionen där användning av litanian, som böneform är begränsad jämfört med den katolska eller ortodoxa liturgin ${ }^{1}$. I Svenska kyrkan förekommer litanian endast som ett moment i mässan och dess adressat är alltid den treeniga Guden ${ }^{2}$. Kring katol-

${ }^{1}$ Diskussionen om betydelsen av litanian i olika kyrkotraditioner kan av utrymmesskäl inte utvecklas i denna text. Att både konfesiella och nationella faktorer påverkar uppfattningen av begreppet litania påpekar Witold Sadowski som har jämfört ett flertal definitoner i väst- och centraleuropeiska uppslagsböcker (Sadowski, 2011:17f).

${ }^{2}$ I 1986 års psalmbok finns tre s.k. Kyrie litanior $(695,696,697)$, som används vid ett fast moment i gudstjänsten som kallas för Kyrie (Kristusrop) och tre litanior avsedda att sjungas som förböner i högmässan (700:1-3). 
ska litanior byggs separata gudstjänster och dessa litanior kan ha olika adressater. De två äldsta och mest kända är litanian till jungfru Maria och helgonlitanian. Den breda kulturella kontext som därmed skapas förblir oftast okänd för icke-katoliker.

Det är också viktigt att påpeka att ordet litania har delvis tappat sin ursprungliga betydelse i modernt svenskt språkbruk och används alltmer frekvent i betydelsen "lång uppräkning av klagomål framförda på ett kverulantiskt sätt" (Svensk ordbok, 1990). Detta kan också förklaras genom att hänvisa till den protestantiska litanian som först och främst associeras med deprekativ bön i nödtid (Bra Böckers Lexikon, 1977). Mot bakgrund av ovanstående är det föga förvånande att det saknas i Sverige litteraturvetenskaplig forskning om lyriska genrer som har sitt ursprung i litaniabönen.

"Litaniadikten i de europeiska regionernas kultur"3 är ett forskningsprojekt som år 2013 inleddes på Warszawauniversitet. Inom ramen för projektet ska det i första skedet undersökas i vilken omfattning litaniadikt förekommer i nationella litteraturer. Arbetsnamnet litaniadikt omfattar lyriska former vars modellrepresentationer är litaniaböner. Ämnesmässigt skilda (både religiös och världslig lyrik kan klassificeras som litaniadikt) tilllämpar litaniadikter liknande kompositions- och rytmiseringsgrepp och därmed skriver de in sig i den breda litaniatraditionen (http://www.wiersz.uw.edu.pl/). Syftet bakom projektet är också att kartlägga de förvandlingar som litaniadikten har genomgått under historiens lopp och förklara dem mot bakgrund av den historiska och samhälleliga utvecklingen för att sedan diskutera frågan i vilken mån litaniatraditionen har påverkat den europeiska verskonsten. Föreliggande artikel är ett utdrag ur en pågående studie om litaniadiktens förekomst i svensk och finlandssvensk litteratur.

Witold Sadowski som är ledare för projektet och pionjär inom litaniaforskningen bjuder i sin bok Poezja $i$ litania på en fördjupad analys av litanians genes, dess genotyp, och den kommunikationsmodell som brukar användas i litanior. I den korta översikten av hans forskningsresultat som följer nedan fokuserar jag framförallt på litaniagenrens tillkomst och litanias genetiska beståndsdelar.

Genren litania har enligt Sadowski utvecklats genom samspel av tre gener som har sitt ursprung i olika kult- och bönetraditioner: DEN EKTENISKA GENEN, DEN POLYONIMISKA GENEN och DEN CHAIRETISMISKA GENEN ${ }^{4}$. Den

\footnotetext{
${ }^{3}$ Det polska projektnamnet är "Wiersz litanijny w kulturze narodów Europy", det engelska "Litanic Verse in the Culture of European Regions. Projektet är finansierat av forskningsanslag som beviljats av Narodowe Centrum Nauki (National Science Center, motsvarighet till det svenska Vetenskapsrådet); bidragsbeslut nummer DEC-2012/07/E/HS2/00665.

4 De ursprungliga polska termena som Sadowski skapat är "gen ektenialny", "gen polionimiczny", "gen chairetyzmiczny", deras engelska motsvarigheter som används inom forskningsprojektet är "the ektenial gene", "the polyonymic gene" och "the chairetismic gene".
} 
ekteniska genen har uppkallats efter bönen ektenia som är en typ av förbön i ortodoxa och östliga kyrkor. EKTENIA består av en serie böneanrop framförda av prästen och åtföljda av menighetens svar i form av böneformel: "Hospodi pomiłuj" - "Herre förbarma dig". Direkt hänvändning till Gud samt en koncentration av verbfraser som ska tillförsäkra de bedjande Guds uppmärksamhet: "vi bönfaller", "bönhör oss", "förbarma dig över oss" är ett annat kännetecknande drag . Den ekteniska genen framstår dock som mycket äldre än dess kristna representationer, därom vittnar likheter mellan ektenia och den fornjudiska bönen PIJJUT som också var en kollektiv bönform. Den framfördes som växelsång mellan celebranten och kören varunder de bedjande dansade i cirkel runt en altare eller runt Torarullarna. Att dans senare ersattes med processionsgång som blev ett komplement till kristna böner av ektenisk karaktär kan förklaras med antika grekers och romares förkärlek för processioner som en del av kult. När de kristna tog över delar av de hedniska ritualerna och fyllde dem med ny mening blev den ekteniska genen överförd till en ny genre - litanian (Sadowski, 2011:29ff).

Den polyonymiska genen har sina rötter i traditionen att kalla en gudom för olika namn, antingen som hyllning, som i flera polyteistika religioner och i islam, eller i syfte att dölja det rätta, tabubelagda namnet, som i judendomen eller i det antika Rom. Att stapla ett antal namn (perifraser eller antonomasior) på varandra i en bön kunde också vara ett försök att gissa gudens okända namn eller åtminstone komma närmare det gömda, gåtfulla namnet (Sadowski, 2011:35ff). Den konstnärligt utformade fornegyptiska bönen "Litania till Ra" (eng. "Litany of Re", ca. 1500 f. Kr) kan betraktas som den mest framträdande illustrationen av den polyonimiska genens förekomst. Solguden hyllas i en serie perifraser, i vilka namnet Ra förses med beskrivningar av gudens handlingsakter som förevigas i en rad inkarnationer (Sadowski, 2011:38f). Genen finns också i Psaltaren och Sadowski hävdar att Psalm 136 har tjänat som en viktig mall för senare kristna litanior $(2011: 40)^{5}$.

Den ekteniska och den polyonymiska genen möttes i den bysantinska liturgin då trishagion, en hymn med polyonymiska invokationer "Helige Herre Gud/ Helige Starke Gud/ Helige Odödlige Gud", kompletterades med en responsorisk bön med suppliker eller skuldbekännelser. Samma typ av möte

${ }^{5}$ I 1917 års översättning förses Psalm 136 med rubriken "Tacksägelse till HERREN för hans stora under och eviga nåd". Här citeras raderna 1-10: "Tacken herrarnas HERRE,/ ty hans nåd varar evinnerligen;/ honom som allena gör stora under,/ ty hans nåd varar evinnerligen;/ honom som har gjort himmelen med förstånd,/ ty hans nåd varar evinnerligen;/ honom som har utbrett jorden över vattnen,/ ty hans nåd varar evinnerligen;/ honom som har gjort de stora ljusen,/ ty hans nåd varar evinnerligen:/ solen till att råda över dagen,/ ty hans nåd varar evinnerligen,/ månen och stjärnorna till att råda över natten,/ ty hans nåd varar evinnerligen;" (http://runeberg.org/bibeln/19_d6.html). 
förekommer i den äldsta av litanior: Helgonlitanian som på 600-talet kom till England från Antiokias Patriarkat. Det polyonimiska inslaget i Helgonlitanian är en uppräkning av helgon- och änglanamn vilka kan betraktas som exemplifikationer av Guds närvaro i skapelsen och antonomasior av Guds namn. Böneformler som bl a: "Kristus bönhör oss", "Bevara oss Herre", "Kom och rädda oss Herre" kommer däremot från den ekteniska genen. Bönen spred sig så småningom över det kristna Europa och fick många lokala och nationella variationer. Sadowski påpekar att Helgonlitanian har blivit en förebild för hela litaniatraditionen (2011:43ff).

Den chairetismiska genen tycks vara svårast att urskilja i en ren form.

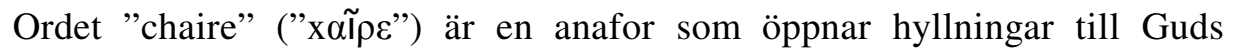
Moder i Akathistos-hymnen, närmare bestämt i det 13-radiga omkvädet som följer efter de ojämnt numrerade stroferna ${ }^{6}$. Eftersom chaire-hyllningar (gr. "chairetismoi") är perifraser av Marias namn kan dessa betraktas som en sammansmältning av två gener, den chairetismiska och den polyonimiska. Sadowski lämnar mycket plats åt att diskutera det semantiska fältet av ordet "chaire". I grekiskan var "chaire" en välkomst- eller avskedshälsning men också en uppmuntrande uppmaning. Verbets infinitiv betyder dock "att glädja sig", "att vara glad", "att finna behag i". I latinsk översättning ersattes därför "chaire" med både "ave" eller "salve" ("var hälsad", "hell dig") och "gaude" ("gläd dig") respektive "vale" ("lev väl"). En annan tolkningsvariant av "chaire" är "benedica" i optativ funktion ("var välsignad") vilket närmar chaire-hyllningarna i Akathistoshymnen till lovprisande böner eller tacksägelseböner i judisk liturgi och får oss att betrakta den omfattande hymntraditionen som analogisk till litaniatraditionen (Sadowski, 2011:52ff). Sadowski förklarar dessutom att "chaire" inte endast behöver uppfattas som ett glädjeutrop utan det kan också härröra från gamla indoeuropeiska besvärjelseriter eller vara ett arkaiskt klagorop ${ }^{7}$. I kristna bönetexter kan det fungera som ett eufemistiskt uttryck för det övernaturliga, det som överskrider människans kognitiva förmåga och det som inte ska begrundas och utforskas (Sadowski, 2011:59).

De första Marialitanior i Västeuropa har sina rötter i Akathioshymen. Som ett tidigt exempel på den fullutvecklade litaniagenren nämner Sadowski Venediglitanian där chairetismiska hyllningar och polyonimiska perifraser

${ }^{6}$ Akathistos är en kontakion, dvs en liturgisk hymn som består av ett antal metriska strofer (oikos) där varje avslutas med ett omkväde. Den första strofen är huvudstrofen, som presenterar hymnens tema. Akathistos består av 24 oikoi vars begynnelsebokstäver bildar det grekiska alfabetet. Vid de jämna oikoi finns omkvädet "Allelouïa", vid de ojämna och vid den inledande strofen omkvädet "Gläd dig, o oförmälda Brud". De ojämnt numrerade oikoi är utvidgade med 12 hyllningar som börjar med ordet "chaire" (Åkerström, 2005).

${ }^{7}$ Sadowski hänvisar bl.a. till Margaret Alexious forskning om rituell klagan i grekisk kultur och Jan Gondas forskning om Rigveda (Sadowski, 2011:54ff). 
kompletteras med bönfallande hänvändelser till Guds Moder tillkomna genom den ekteniska genen. I Venediglitanians uppräkning av Marias egenskaper jämställs hälsningen "ave", som har sitt ursprung i chairehälsningar, med epiteten "sankta" som är känd från den polyonimiska Helgonlitanian vilket vittnar om ett fortskridande närmande mellan dessa två arketextuella strategier (Sadowski, 2011:63ff).

Bakom den ekteniska genen anar Sadowski ett flyktförsök och ett rop om hjälp i nöden, den polyonimiska genen tolkar han som en vilja att tränga in $\mathrm{i}$ en hemlighet, $\mathrm{i}$ den chairetismiska genen ser han en pendelrörelse mellan glädje och smärta (Sadowski, 2011:67). Böner som är förankrade i de respektive generna har därför haft olika funktioner, vilket också har påverkat sättet att be: den ekteniska vädjan om hjälp och förlåtelse ska framföras rytmiskt medan man dansar eller går i procession, den polyonimisk åkallan och tacksägelsen får en form av lågmäld meditation, den chairetismiska trosbekännelsen och lovprisningen är en expressiv bön med glädjeutrop eller klagorop. De frekvent använda ekteniska böneformlerna är "Kyrie eleison", "Miserere nobis", "Exaudi nos", "Libera nos Domine", de chairetismiska - "Chaire", "Shalom", "Benedicta". Formeln "Sanctus" är typisk för polyonimiska böner. Olika bönetyper har dessutom en bestämd komposition och använder sig av specifika stilistiska medel. En ektenisk bön utformad som växelsång mellan prästen och menigheten innehåller uppräkningar och parallellismer samt apostroferingar. Uppräkningar, anaforer, epiforer, parallellismer, perifraser, onomata, epiteter, antonomasior är karakteristiska för en polyonimisk bön. I en chairetismisk bön brukar upprepningar, omkväden, apostroferingar användas.

Samspelet mellan dessa tre litaniegener innebär att de tillsammans skapar en föreställningsvärld som öppnar sig bakom varje litania: ”De enskilda representationer av genren litania behöver inte använda alla tre gener, men varje bön framförs mot en osynlig semantisk bakgrund som kommer till uttryck i bönens ton: den polyonymiskt ihärdiga, den ekteniskt enträgna, den chairetismiskt koncentrerade, den polionimiskt utspridda, den ekteniskt avhängiga, den chairetismiskt förtroliga (...)".8

Sadowskis resonemang har jag tillämpat på Karin Boyes dikt "Bön till solen". Analysens mål är att peka på litaniadrag i dikten och därmed placera den i litaniatraditionen.

8 "Poszczególne litanie nie zawsze wykorzystują wszystkie trzy geny, ale każdej modlitwie wtóruje niewidzialne tło semantyczne, wyrażane w tonie wypowiadania tekstu: polionimiczna uporczywość, ektenialna natarczywość, chairetyzmiczne skupienie, polionimiczne rozproszenie, ektenialna zależność, chairetyzmiczna zażyłość; (...)" (Sadowski, 2011:68, min översättning). 


\section{KARIN BOYE "BÖN TILL SOLEN"}

Skoningslöse med ögon som aldrig har sett mörkret!

Frigörare som med gyllene hamrar bräcker isar!

Rädda mig!

Raka som smala streck sugs blommornas stänglar i höjden:

närmare dig vill kalkarna skälva.

Träden slungar sin kraft som pelare mot sin härlighet:

först där uppe

breder de ut sin ljustörstiga bladfamn, hängivna.

Människan drog du

från en jordfast sten med blinda blickar

till en vandrande vajande växt med himmelsvind om pannan.

Din är stängel och stam. Din är min ryggrad.

Rädda den.

Inte mitt liv. Inte mitt skinn.

Över det yttre råder inga gudar.

Med släckta ögon och brutna lemmar

är den din, som levde rak,

och hos den som dör rak

finns du, när mörker slukar mörker.

Mullret stiger. Natten sväller.

Livet skimrar så djupt dyrbart.

Rädda, rädda, seende gud,

vad du skänkte.

(Boye, 1993:191)

Dikten "Bön till solen" är hämtad från Karin Boyes fjärde diktsamling För trädets skull som publicerades år 1935. Den kom ut åtta år efter samlingen Härdarna och året efter den personligt präglade romanen Kris. Även om Boyes tidigare lyriska skapande redan hade en modernistisk anstrykning framstår För trädets skull som genomgående modernistisk såväl när det gäller formen som bildspråket. Denna radikala förändring bemöttes med oförståelse av en del kritiker som ansåg dikterna vara dunkla och svårbegripliga och deras metaforik tillkonstlad (Abenius, 1965:217ff). De som uppskattade samlingen berömde däremot den storartade formförnyelsen och bevittnade den nyuppnådda konstnärliga mognaden (Abenius, 1965:223ff). Idag är litteraturvetarna eniga om att dikterna i För trädets skull har försäkrat Boye en plats bland svenska modernismens klassiker. En träffsäker karakteristik av samlingen har formulerats av Anders Palm som åberopar den psykoanalytiska litteraturforskningens teori om "dikten som begär" och anser den vara särskilt 
adekvat vid tolkning av Boyes dikter: "Lyriken i För trädets skull drivs av en lidelse som är både sinnlig och andlig. Dikterna står nära ett mänskligt du och söker den livsförklaring som bara en gud kan ge. Gränserna mellan erotik och religiös mystik plånas ut" (1999:38).

Diktsamlingens titel är förankrad i en rik föreställningsvärld eftersom trädet syns vara en av Boyes mest omtyckta symboler. Enligt Margit Abenius, diktarens väninna och biograf, står trädet för helhet och harmoni men också för den fria och "rakvuxna" individen (1965:231). "Med sitt rotsystem, sin raka stam, sin grönskande krona blir trädet en bild för människans villkor av bundenhet och frihet, hennes växande och vissnande, hennes strävan ur mörker mot ljus", förklarar Anders Palm i sin sentida essä om Boyes författarskap (1999:38). För trädets skull är en fras hämtad ur dikten "Trädet under jorden", men boken skulle först heta Martall som en av dikterna i den (Abenius, 1965:216). Hade denna titel behållits skulle den ha gett samlingen en dystrare klang. Martallarna kämpar tappert mot blåsten men de kan inte ändra det öde de är dömda till. De kommer aldrig att närma sig det ideal som förkroppsligas av rakstammiga ekar, björkar eller lönnar: "Göm dina drömmar, krympling./ Här är de yttersta skären. Så långt ögat når: martall” (Boye, 1993:201). Potentialen som finns i trädet som växer under jorden är däremot ännu oförlöst, processen att växa är visserligen smärtsam men det finns ett hopp om befrielse: "Där våndas ett träd i tunga lager av jord./ Å vind! Solljus!/ Känn den våndan: löften om doft av paradisunder" (Boye, 1993:106).

Dikterna i För trädets skull är skrivna av en mogen ordkonstnär som medvetet sätter språkets möjligheter på prov och vågar utmana reglerna och tänja gränserna för vad en dikt kan vara ${ }^{9}$. Men de är också skrivna av en sökare som bland trossystem, filosofiska läror och vetenskapliga teorier försöker hitta svar på frågor om mål och mening med livet och förklaring till den spänning mellan ytterligheter som diktaren hela livet brottades med. Det är värt att påminna att vid den tidpunkt då samlingen publicerades hade Karin Boye bakom sig tonårens fascination över buddhismen och Schopenhauer, en entusiastisk omvändelse till kristendomen som kom i artonårsåldern och en allvarlig troskris som följde några år senare och ledde till depression. Hon intresserade sig för psykoanalysen och gick själv i psykoanalytisk terapi och den inlevelsefulla läsningen av Nietzsche blev hennes stora inspiration i sökandet efter "en okänd gud, verksam i människans inre" (Palm, 1999:38).

Med hänsyn till all erfarenhet som diktaren samlat är det inte förvånande att flera dikter i För trädets skull har en religiös dimension. Abenius hävdar att "[d]ikternas stämning förmedlar någonting högtidligt och skakande, något

${ }^{9}$ Om behovet att skapa ett personligt symbolspråk som möjliggör en att utforska sitt inre skrev Boye i artikeln "Språket bakom logiken" som publicerades i Spectrum 1932. Artikelns titel brukar ofta citeras som karakteristik av modernisternas språk (Palm, 1999:38; Espmark, 1977:219). 
sakralt som närmar dem till antik poesi” (1965:244). Detta kan också observeras på språknivån i talrika hänvisningar till symboler, trosföreställningar och kulthandlingar. Jaget knäböjer och "dricker ur jordens ådror dess sakrament" i dikten "Ingenstans" (Boye, 1993:169) och i "Mogen som en frukt" blir jaget "dränkt i en mognads dop" och "helgad till handling" (Boye, 1993:181). Boye anspelar på Bibelns ord när hon avslutar kärleksdikten "Blonda morgon" med frasen "morgon på den sjunde dagen" (Boye, 1993:180) ${ }^{10}$. En annan kärleksdikt inleds med raden " Den vägen är smal som två har att gå" ("Den vägen är smal", Boye, 1993:206) ${ }^{11}$. Det är inte bara de kristna koderna som diktaren behärskar utan hon rör sig fritt mellan olika trosläror. I samlingen finns två dikter som har ordet "bön" i titeln: "Bön till solen", som jag analyserar nedan, och "Havsbönen". Bönekomponenter och böneformler kan också urskiljas i några andra dikter i samlingen, något som jag ska återkomma till i slutet av mitt resonemang.

"Bön till solen" var en av de dikter som vid sidan av "Ja visst gör det ont" och "Bål" utmärktes i recensionerna publicerade vid samlingens utkomst. Dikten påminner i flera avseenden om litanian. Genretypiska drag gör sig synliga redan i den första treradiga sekvensen som består av två apostroferingar av polyonimisk karaktär åtföljda av böneformeln "Rädda mig" som hör hemma i den ekteniska traditionen. Denna vädjan om hjälp upprepas sedan i dikten i varierade former, sammanlagt tre gånger.

Att det är solen som tilltalas och tillbes framgår endast av diktens titel, i texten ersätts ordet "sol" med perifraser. Benämningar [den] "skoningslöse" i den första versraden och "frigörare" i den andra kompletteras med hjälp av utbyggda satsattributiva bestämningar. Den första perifrasen syftar på en egenskap: "Skoningslöse med ögon som aldrig har sett mörkret!" Den andra beskriver en handlingsakt: "Frigörare som med gyllene hamrar bräcker isar!" Solen framstår som ett obestridligt objekt för dyrkan och i diktens slutrader blir solens gudomliga natur bekräftad med det tredje namnet: "seende gud".

Tagna ur sitt sammanhang kan perifraserna tyckas motsäga varandra. Solen är den som inte känner medlidande men samtidigt den som befriar. I sitt försök att avkoda solsymbolen hänvisar Abenius dels till Boyes intresse för psykoanalysen som skoningslöst genomskådar medvetandet, dels till diktarens egna ord att solen betydde för henne tankefriheten (Abenius, 1965:233). Om vi betraktar diktens två första rader som litaniainvokationer ligger en annan tolkning nära till hands, nämligen att det handlar om två olika perspektiv

10 "Den sjunde dagen hade Gud fullbordat sitt verk, och han vilade på den sjunde dagen efter allt han hade gjort" (1 Mosebok 2:2, Bibel 2000).

11 "Gå in genom den trånga porten. Ty den port är vid och den väg är bred som leder till fördärvet, och det är många som går in genom den. Men den port är trång och den väg är smal som leder till livet, och det är få som finner den" (Matt. 7:13-14, Bibel 2000). 
i synen på gudomen: "skoningslös" är ett tillnamn på solguden i strid med sin dödsfiende - mörker och "frigörare" är en hederstitel som myntats av tacksamma bekännare.

Margit Abenius kallar "Bön till solen" för "ett av de mest förtätat poetiska uttrycken för den uppåtsträckta extatiska rörelse av dyrkan som redan den mycket unga Karin Boye famlade efter att fånga på sin barndoms skissblock i sköna soldyrkande gestalter" (1965:233). I diktens andra sekvens utövar blommor och träd soldyrkan med hela sitt väsen: "Raka som smala streck sugs blommornas stänglar i höjden:/ närmare dig vill kalkarna skälva./ Träden slungar sin kraft som pelare mot sin härlighet:/ först där uppe/ breder de ut sin ljustörstiga bladfamn, hängivna."

Hyllningsakten tycks här vara en förlängning av skapelseakten. Bakom bilden av raka stängslar och stammar, skälvande blomkalkar och hängivet utbredda trädkronor som vill komma närmare sin välgörare ser vi solguden som skänker ljus och värme och därmed ger kraft till att sträcka sig upp efter mer. Hela stycket kan därför uppfattas som ännu en perifras av solens namn och tolkas som en polyonymisk-chairetismisk litaniainvokation med betydelsen: "Var hälsad du, som får blommor och träd att växa och prisa dig". En liknande tolkning kan tillämpas på nästa textstycke, där solguden karakteriseras genom en av sina handlingar, det vill säga som den drivande kraften bakom människans frigörelse och omvandling: "Människan drog du/ från en jordfast sten med blinda blickar/ till en vandrande vajande växt med himmelsvind om pannan". I översättning till ett klassiskt litaniaspråk får vi då en invokation som lyder: "Var hälsad du som frälste den jordbundna människan och fick henne att drömma och sträva efter höga ideal".

Den lovprisande delen av dikten avslutas med en vigningsakt där jaget, likt blomman och trädet, överlåter sig åt solguden: "Din är stängel och stam. Din är min ryggrad." Vädjan "Rädda den" som öppnar den tredje sekvensen och diktens bönfallande, ekteniska del syftar på det föregående ordet "ryggrad". Människans ryggrad motsvarar blommans stängel och trädets stam och utgör den bärande konstruktion som gör det möjligt att hålla en upprätt ställning. Men det är inte bara det kroppsliga skalet som ryggraden bär upp utan först och främst den andliga strävan efter höga ideal. Ryggraden står för människans moral, redlighet, för det rena, ädla och sanna. En nyckel till att förstå diktjagets bön till solen är därför ordet "rak": "Med släckta ögon och brutna lemmar/ är den din, som levde rak,/ och hos den som dör rak/ finns du, när mörker slukar mörker." När rädslan stiger och döden närmar sig gäller det att uthärda och förbli trogen sina principer. Medan det yttre är dömt till att förgås har den raka hållningen ett evinnerligt värde, den "framstår i dödsögonblicket som livets högsta vinning" (Abenius, 1965:233). Den raka hållningen är solgudens gåva och därför avslutas dikten med den tredje "rädda"-vädjan: "Rädda, rädda seende gud,/ vad du skänkte." 
De dystra stämningar som förmedlas mot diktens slut strider mot de livsbejakande hyllningsakter som öppnar den. Raden "Mullret stiger, natten sväller" kan man tolka som en föraning om en annalkande fara, omöjlig att stoppa."Författarinnan anar undergången och martyrernas kamp" skriver Abenius och åberopar Gunnar Tidströms analys, där "Bön till solen" kallas för en tidsdikt (1965:233). Visionen kan syfta på situationen i världen vid totalitarismernas framväxt före andra världskrigets utbrott men också avspegla diktarens psykiska kondition: Boye tog sitt liv år 1941 efter en rad självmordsförsök."Livsberusningen i Karin Boyes sena diktning flammar upp mot en mörk bakgrund. Både i sin egen tillvaro och i världen såg hon förgörelsens makter närma sig. Avståndet mellan livsbegär och dödsdrift blev allt kortare”, konstaterar Palm (2011:40).

"Vilken tragisk och avgjort individualistisk vision av människan som innerst behärskar Karin Boyes humanism", utropar Bertil Malberg i sin recension av För trädets skull och citerar som bevis slutdelen av "Bön till solen" (Abenius, 1965:217). Man kan undra om skiljelinjen mellan det individuella och det kollektiva verkligen är så tydlig i dikten. Den bön om räddning som framförs av diktjaget kan tyckas ensam och enstämmig, präglad av personliga tvivel och farhågor. Men i hyllningen till solen smälter diktjaget samman med den personifierade naturen och blir en röst i kören av tacksamma väsen. Enligt Abenius är den eftersträvade raka hållningen också "något som ger del i den ande som når utöver det individuella" (1965:233). Som ett försök till att ge dikten en universell dimension kan dessutom tolkas konstruktionerna "den (...) som levde rak", "den som dör rak". Pronomen "den" kan visserligen syfta på en utvald individ som utmärker sig i mängden men i diktens kontext tycks den snarare referera till alla som uppfyller detta krav. Abenius upplyser om att Boye har ändrat slutraderna i dikten som i den första versionen lydde "Rädda, rädda mig, seende gud,/ från att fegt böja mig." "2 Detta har förorsakat en signifikant budskapsförskjutning. Den ekteniska vädjan "Rädda, rädda seende gud,/ vad du skänkte" bör inte tolkas endast som en privat bön. Den omfattar alla som har fått solens gåva och alla som hyllar solguden och överlåter sig till den är välkomna att instämma i den.

Analysen av "Bön till solen" ger vid handen att alla tre gener som Sadowski anser vara litanians byggstenar kan spåras i dikten. Den polyonimiska genen som kommer till uttryck i perifraser av solgudens namn svarar för lovprisning och tillbedjan av solen som är en skapande och givande kraft. Den ekteniska genen genljuder i vädjan "rädda" som utgör en bönerefräng och avslöjar jagets splittring mellan viljan att förbli "rak" och bävan för att bli tvungen att böja sig. Den chairetismiska genen kan visserligen inte identifieras på språknivån men den skymtar på bildnivån både i extatiska hyllningsakter till

\footnotetext{
${ }^{12}$ Innan "Bön till solen" ingick i samlingen För trädets skull publicerades dikten i Presens 1934, nr 3 (Abenius, 1965: 234).
} 
solen och i diktjagets dystra visioner om den eviga kampen mellan det ljusa och det mörka, mellan livet och döden. Dikten kan inte klassificeras som en klassisk litania, men den bär på minnen om den genre som idag förefaller så gott som glömd i Sverige.

"Bön till solen" är inte den enda dikten av Karin Boye som har litaniadrag. Hon har i hela sitt lyriska författarskap visat förkärlek för de stilistiska figurer och kompositionsgrepp som är karakteristiska för litaniagenren. I synnerhet gäller det anaforer, uppräkningar, paralleller och omkväden som Boye gärna har använt sig av för att rytmisera dikten. Apostroferingar och perifraser hör också till de stilistiska medel som återkommer i dikterna. Som ett exempel på litaniastilisering kan också de böneformler betraktas som i omskriven eller parafraserad form har flätats in i några dikter i samlingen För trädets skull. "Helig, helig, helig/ är sanningen, den förfärande,/ jag vet det, jag böjer mig,/ och den har rätt till allt" läser vi $i$ "Ögonen är vårt öde" (Boye, 1993:187). I "Bekännelsen" parafraseras anropet "Sanctus" då jaget beskriver sig själv som "feg, feg, trefalt feg" (Boye, 1993:190). "Trädet under jorden" innehåller en hel litaniapassus. I den bön om frigörelse för det ofödda trädet som avslutar dikten har anropet "Kyrie eleison" skrivits om till till besvärjelsen "För trädets skull, förbarma er!":

\author{
Var vandrar ni fötter, som trampar \\ så mjukt eller hårt \\ att skorpan remnar och ger sitt byte ifrån sig? \\ För trädets skull, förbarma er! \\ För trädets skull, förbarma er! \\ För trädets skull kallar jag er ur de fyra väderstrecken! \\ (Boye, 1993:186)
}

Med tanke på att litaniabönen sedan reformationen har trätt i bakgrunden i Svenska kyrkans liturgi och därmed blivit en halvglömd genre kan man undra varifrån litaniainspirationerna i Boyes författarskap kommer. Den ena tolkningen kan vara att hon har sökt sig till de uttrycksmönster som har bevarats i den svenska litterära traditionen i ett slumrande tillstånd (bl. a. i folkballader och psalmer) och aktualiserats vid enstaka tillfällen av hennes föregångare ( $\mathrm{t}$ ex Gustaf Fröding och Erik Axel Karlfeldt). Litaniaminnen i Boyes dikter kan också vara en del av det gemensamma europeiska arvet som den belästa diktaren har tagit intryck av.

\title{
LITTERATUR
}

Abenius, M. (1965). Karin Boye. Stockholm: Aldus/Bonnier.

Bibeln 2000. (1999). Örebro: Bokförlaget Libris. 
Bibeln eller Den Heliga Skrift innehållande Gamla och Nya Testamentets kanoniska böcker $i$ överensstämmelse med den av Konungen år 1917 gillade och stadfästa översättningen. (1999). Projekt Runeberg. Hämtad från http://runeberg.org/bibeln/19_d6.html (2015.02.24).

Boye, K. (1993). Dikter. Stockholm: Albert Bonniers Förlag.

Bra Böckers Lexikon. Band 14. (1977). Stockholm: Bokförlaget Bra Böcker Abm.

Den svenska psalmboken. (1986). Stockholm: Verbum.

Espmark, K. (1977). Själen i bild. En huvudlinje i modern svensk poesi. Stockholm: P.A. Norstedts \& Söners förlag.

Palm, A. (1999). Tradition i förvandling I - lyriken mellan nittiotalism och modernism.

I: L. Lönnroth et al. (red.), Den svenska litteraturen. Från modernism till massmedial marknad 1920-1995 (p. 23-63). Stockholm: Albert Bonniers Förlag.

Sadowski, W. (2011). Litania i poezja. Na materiale literatury polskiej od XI do XXI wieku. Warszawa: Wydawnictwa Uniwersytetu Warszawskiego.

Svensk ordbok. (1990). Band 1 A-M. Stockholm: Norstedts.

Wiersz litanijny w kulturze regionów Europy: http://www.wiersz.uw.edu.pl/ (2015.03.04).

Åkerström, A. (2005). Glädjens hyllnigar till Gudaföderskan. Hämtad från http://www.ortodoxa kyrkan.se/teol/ (2015.02.24).

\section{Magdalena Żmuda-Trzebiatowska}

Uniwersytet im. Adama Mickiewicza w Poznaniu

Katedra Skandynawistyki

al. Niepodległości 4

61-874 Poznań

Poland

magdazt@amu.edu.pl 